\title{
Pengaruh Penerapan Model Pembelajaran Contextual Teaching and Learning terhadap Kemampuan Komunikasi Matematis berdasarkan Self Confidence Siswa SMP/MTs
}

\author{
Siti Rahmi*, Hasanuddin** \\ * Pendidikan Matematika, Universitas Islam Negeri Sultan Syarif Kasim Riau \\ ** Pendidikan Matematika, Universitas Islam Negeri Sultan Syarif Kasim Riau
}

\begin{tabular}{l} 
INFO ARTIKEL \\
\hline Riwayat Artikel: \\
Diterima: 23-11-2019 \\
Disetujui: 15-12-2019 \\
\hline Kata kunci: \\
Contextual Teaching and Learning \\
Komunikasi Matematis \\
Self Confidence \\
Anova dua-arah \\
Variabel moderator
\end{tabular}

Alamat Korespondensi:

ABSTRAK

Abstract: This study aims to determine the effect of 'Contextual Teaching and Learning' on students 'mathematical communication skills in terms of students' self-confidence. This research uses factorial design. The population in this study were all students of class VII Madrasah Tsanawiyah Ansharullah Birandang Island in the academic year 2018/2019. The sample of this study is students of class VII.B as an experimental class and class VIII as a control class. The instrument used was a questionnaire instrument to measure the level of students 'Self Confidence and description tests to measure students' mathematical communication skills. Data were analyzed using two-way ANOVA. Based on the results of data analysis, it can be concluded that: 1) There are differences in mathematical communication skills between students who take the CTL learning model and students who take conventional learning. 2) There is no influence of the interaction between CTL learning models with Self Confidence on students' mathematical communication skills. Thus in general the CTL learning model influences students' mathematical communication skills.

\begin{abstract}
Abstrak: Penelitian ini bertujuan untuk mengetahui pengaruh 'Contextual Teaching and Learning' terhadap kemampuan komunikasi matematis siswa ditinjau dari self-confidence siswa. Penelitian ini menggunakan disain faktorial. Populasi dalam penelitian ini adalah seluruh siswa kelas VII Madrasah Tsanawiyah Ansharullah Pulau Birandang tahun ajaran 2018/2019. Sampel penelitian ini adalah siswa kelas VII.B sebagai kelas eksperimen dan kelasVII.A sebagai kelas kontrol. Instrumen yang digunakan adalah instrumen angket tuntuk mengukur tingkat Self Confidence siswa dan tes uraian untuk mengukur kemampuan komunikasi matematis siswa. Data dianalisis dengan menggunakan anova dua arah. Berdasarkan hasil analisis data dapat diambil kesimpulan bahwa: 1) Terdapat perbedaan kemampuan komunikasi matematis antara siswa yang mengikuti model pembelajaran CTL dengan siswa yang mengikuti pembelajaran konvensional. 2) Tidak terdapa tpengaruh interaksi antara model pembelajaran CTL dengan Self Confidence terhadap kemampuan komunikasi matematis siswa. Dengan demikian secara umum model pembelajaran CTL berpengaruh terhadap kemampuan komunikasi matematis siswa.
\end{abstract}

\footnotetext{
Siti Rahmi,

Program Studi Pendidikan Matematika

Universitas Islam Negeri Sultan Syarif Kasim Riau

Jl. HR. Soebrantas KM 15.5 Pekanbaru, 28293

E-mail: siti.rahmi@student.uin-suska.ac.id
}

\section{LATAR BELAKANG}

Matematika memiliki peran yang penting dalam mengembangkan kemampuan matematis siswa. Kemampuan komunikasi (mathematical comunication) merupakan salah satu kemampuan matematis yang harus dimiliki siswa (National Council of Teachers of Mathematics, 2000). Tujuan pembelajaran matematika sebagaimana yang tertuang dalam Peraturan Pendidikan Menteri Pendidikan Nasional (Menteri Pendidikan dan Kebudayaan Republik Indonesia, 2013; Menteri Pendidikan Nasional, 2006) terkait kemampuan komunikasi adalah agar siswa mampu mengkomunikasikan gagasan dengan simbol, tabel, diagram, atau media lain yang memperjelas keadaan atau masalah. Oleh karena itu, kemampuan komunikasi matematis merupakan salah satu aspek penting yang perlu menjadi fokus perhatian dalam pembelajaran. 
Kemampuan Komunikasi di Indonesia masih tergolong rendah. Hal ini dapat dilihat dari hasil survey kemampuan yang dilakukan oleh TIMSS (The Trends in International Mathematics and Science Study) dan PISA (Program For International Students Assessment) dalam bidang matematika. Tes yang diberikan TIMSS menitikberatkan pada kemampuan knowing sebanyak 35\%, applying sebanyak $40 \%$ dan reasoning sebanyak $25 \%$, sedangkan tes PISA menitikberatkan pada kemampuan pemecahan masalah, penalaran dan komunikasi. Pada tahun 2012 berdasarkan hasil PISA Indonesia berada diperingkat 64 dari 65 negara dan pada tahun 2015 indonesia berada diperingkat 63 dari 70 negara(OECD, 2018). Selain itu, hasil survey TIMSS menunjukkan prestasi Indonesia berada pada peringkat 34 dari 38 negara tertinggal dari Negara Malaysia, Thailand dan Singapore (Ina V.S. Mullis, Michael O. Martin, Pierre Foy, \& Alka Arora, 2012).

Kemampuan komunikasi matematis siswa masih tergolong rendah (Wijayanto, Fajriah, \& Anita, 2018, p. 98). Berbagai Riset telah dilakukan untuk meningkatkan kemapuan komunikasi matematis (Abdi \& Hasanuddin, 2018; Firmansyah, Hasanuddin, \& Nelson, 2018; Rahmayanti, Hasanuddin, \& Nelson, 2018; Syasri, Hasanuddin, \& Noviarni, 2018; Wahyuni, Hendryawan, Nasrullah, \& Wachyar, 2018), Siswa cenderung mengalami kesulitan dan melakukan kesalahan saat menyatakan permasalahan dari soal kedalam notasi dan simbol matematika. Berdasarkan observasi yang peneliti laksanakan di salah satu MTs di Kabupaten Kampar menunjukkan bahwa kemampuan komunikasi siswa masih tergolong rendah. Hal ini dapat dilihat dari kondisi siswa yang mengalami kesulitan dalam menjelaskan ide-ide matematika, melakukan kesalahan dalam menggunakan notasi, simbol, dan istilah matematika.selain itu, dalam proses pembelajaran sebagian besar siswa masih tergolong pasif, belum menunjukkan antusias dan keaktifannya untuk mengungkapkan ide atau pendapat.

Model pembelajaran Contextual Teaching And Learning (CTL) merupakan salah satu alternatif model pembelajan yang dapat meningkatkan kemampuan komunikasi matematis siswa. CTL adalah suatu tekhnik pembelajaran yang menitikberatkan pada keterlibatan siswa secara maksimal dalam rangka menemukan materi yang dipelajari dan hubunganya dengan situasi dunia nyata. Pembelajaran dengan model CTL dapat menumbuhkan keaktifan siswa dan mempermudah penalaran atau berfikir logis sehingga siswa memiliki kemampuan untuk mengkomunikasikan.

Selain komunikasi matematis, Self Confidence (kepercayaan diri) siswa pun yang juga menunjang kemampuan dan keberhasilan siswa dalam pembelajaran matematika. Siswa dengan Self Confidence yang baik akan memperoleh dorongan untuk lebih aktif dan membantunya mengambil keputusan dalam menyelesaikan suatu permasalahan. Sebaliknya Self Confidence yang tidak baik akan menjadikan siswa bersikap lebih pasif dalam proses pembelajaran dan menjadikan siswa bersikap enggan untuk aktif dalam kegiatan kelas. Hal ini didukung oleh hasil penelitian Mulis dan rahmat yang mengungkapkan bahwa "terdapat asosiasi positif antara kepercayaan diri dalam belajar matematika dengan hasil belajar matematika” (Hendriana, Rohaeti, \& Sumarmo, 2017).

Berdasarkan uraian permasalahan tersebut, penelitian ini bertujuan untuk menyelidiki: (1) ada atau tidaknya perbedaan kemampuan komunikasi matematis antara siswa yang belajar dengan model pembelajaran Contextual Teaching And Learning dengan siswa yang belajar menggunakan pembelajaran konvensional; (2) ada atau tidaknya interaksi antara model pembelajaran Contextual Teaching and Learning terhadap self confidence siswa dalam meningkatkan kemampuan komunikasi matematis siswa.

\section{METODE}

\section{Jenis dan Desain Penelitian}

Jenis penelitian yang digunakan dalam penelitian ini adalah dengan desain faktorial. Rancangan penelitian diterapkan pada situasi yang berbeda yaitu kelas eksperimen akan diterapkan model pembelajaran CTL dan kelas kontrol akan diterapkan pembelajaran konvensional. Rancangan ini diuraikan dalam bentuk tabel berikut :

Tabel 1. Hubungan antara Model Pembelajaran dan Self Confidece siswa dengan Kemampuan Matematis

Kelas

\begin{tabular}{|c|c|c|}
\hline \multirow[b]{2}{*}{ self Confidence } & \multicolumn{2}{|c|}{ Pemahaman Konsep Matematis Siswa } \\
\hline & $\begin{array}{c}\text { Pembelajaran } C T L \\
\left(\mathrm{D}_{1}\right)\end{array}$ & $\begin{array}{l}\text { Pembelajaran konvensional } \\
\qquad\left(\mathrm{D}_{2}\right)\end{array}$ \\
\hline Tinggi $\left(E_{1}\right)$ & $\mathrm{D}_{1} \mathrm{E}_{1}$ & $\mathrm{D}_{2} \mathrm{E}_{1}$ \\
\hline Sedang $\left(E_{2}\right)$ & $\mathrm{D}_{1} \mathrm{E}_{2}$ & $\mathrm{D}_{2} \mathrm{E}_{2}$ \\
\hline Rendah $\left(E_{3}\right)$ & $\mathrm{D}_{1} \mathrm{E}_{3}$ & $\mathrm{D}_{2} \mathrm{E}_{3}$ \\
\hline
\end{tabular}

\section{Kterrangan:}

$\mathrm{D}_{1} \quad$ : Kemampuan komunikasi matematis siswa terhadap model pembelajaran CTL

$\mathrm{D}_{2} \quad$ : Kemampuan komunikasi matematis siswa matematis siswa terhadap model pembelajaran konvensional

$\mathrm{D}_{1} \mathrm{E}_{1}$ : Kemampuan komunikasi matematis siswa dengan self confidence tinggi yang diajarkan dengan model pembelajaran CTL

$\mathrm{D}_{1} \mathrm{E}_{2}$ : Kemampuan komunikasi matematis siswa dengan self confidence sedang yang diajarkan dengan model pembelajaran CTL

$\mathrm{D}_{1} \mathrm{E}_{3}$ : Kemampuan komunikasi matematis siswa dengan self confidence rendah yang diajarkan dengan model pembelajaran CTL 
$\mathrm{D}_{2} \mathrm{E}_{1}$ : Kemampuan komunikasi matematis siswa dengan self confidence tinggi yang diajarkan dengan model pembelajaran konvensional.

$\mathrm{D}_{2} \mathrm{E}_{2}$ : Kemampuan komunikasi matematis siswa dengan self confidence sedang yang diajarkan dengan model pembelajaran konvensional.

$\mathrm{D}_{2} \mathrm{E}_{3}$ : Kemampuan komunikasi matematis siswa dengan self confidence rendah yang diajarkan dengan model pembelajaran konvensional.

\section{Tempat dan Waktu Penelitian}

Penelitian ini dilaksanakan di MTs Ansharullah Pulau Birandang pada siswa kelas VII semester genap tahun ajaran $2018 / 2019$.

\section{Populasi dan Sampel Penelitian}

Populasi dalam penelitian ini adalah seluruh siswa kelas VII MTs Ansharullah. Teknik pengambilan sampel yang digunakan adalah purposive sampling. Purposive Sampling yaitu teknik pengambilan sampel dengan memikirkan pertimbangan tertentu (Sugiyono, 2012). Adapun pertimbangan disini adalah dengan melihat sifat homogenitas siswa yang juga ditunjang oleh keterangan guru yang mengajar di kelas yang mengatakan bahwa kedua kelompok siswa yang dijadikan sampel tersebut memiliki kemampuan komunikasi matematis dan Self confidence yang sama, sehingga bisa dijadikan sampel penelitian. Untuk memperkuat keterangan tersebut Sebelum sampel diberi perlakuan, maka kedua kelas tersebut tetap di uji normalitas dan homogenitas kemampuan komunikasi matematis serta Uji-t dengan mengggunakan nilai uji kesamaan. Sampel yang diambil dalam penelitian ini adalah kelas VII B yang berjumlah 30 orang sebagai kelas eksperimen yang akan diberi perlakuan dengan menerapkan model pembelajaran CTL dan kelas VII A yang berjumlah 30 orang sebagai kelas kontrol yang akan diberi perlakuan dengan menerapkan model pembelajaran konvensional.

\section{Teknik Analisis Data}

Teknik analisis data dalam penelitian ini meliputi: 1) uji normalitas untuk mengetahui apakah sampel berdistribusi normal, menggunakan chi kuadrat; 2) uji homogenitas untuk mengetahui apakah beberapa data varian homogen atau tidak, menggunakan uji F; dan 3) uji hipotesis menggunakan uji-t untuk hipotesis pertama dan uji anova dua arah untuk hipotesis ketiga.

\section{HASIL DAN PEMBAHASAN}

Hasil perhitungan terhadap uji-t dapat dilihat pada tabel berikut:

Tabel 2. Hasil Uji Tes-t

\begin{tabular}{ccl}
\hline $\boldsymbol{t}_{\text {hitung }}$ & $\boldsymbol{t}_{\text {tabel }} \mathbf{5} \%$ & Keterangan \\
\hline 2.02 & 1.67 & Ha diterima \\
\hline
\end{tabular}

Hasil perhitungan terhadap uji anova dapat dilihat pada tabel berikut:

Tabel 3. Hasil Uji Anova Dua Arah

\begin{tabular}{cccccc}
\hline Varians & Dk & Jk & Rk & Fh & Fk \\
\hline A & 1 & 866.4 & 866.4 & 10.278 & 4.02 \\
B & 2 & 7656.085 & 3828.04 & 45.41 & 3.17 \\
$($ AxB $)$ & 2 & -331.949 & -165.97 & -1.97 & 3.17 \\
\hline
\end{tabular}

\section{Uji Hipotesis I}

Berdasarkan analisis data tes yang telah dilakukan, diperoleh bahwa kemampuan komunikasi matematis siswa kelas eksperimen lebih baik dari pada kelas kontrol. Analisis data menunjukkan selisih rerata kemampuan komunikasi matematis kelas eksperimen dan kelas kontrol sebesar 7.6 dengan mean kelas eksperimen dan mean kelas kontrol secara berturut adalah 72.23 dan 64.63. Berdasarkan perhitungan uji-t hipotesis pertama diperoleh $t_{\text {hitung }}=2.02$ dan $t_{\text {tabel }}=1.67$. Karena $t_{\text {hitung }}>t_{\text {tabel }}$. maka $H_{a}$ diterima dan $H_{o}$ ditolak, artinya kedua kelas memiliki perbedaan kemampuan komunikasi matematis. Hal ini berarti bahwa penerapan model pembelajaran CTL memiliki dampak positif terhadap kemampuan komunikasi matematis siswa.

Begitu juga dengan self confidence siswa, berdasarkan hasil nilai angket self confidence siswa pada kelas eksperimen memperoleh rata-rata sebesar 7.29 dan kelas kontrol sebesar 6.56. Pengelompokkan self confidence siswa, dengan rentang nilai $X \leq 67.56$ untuk kategori rendah,67.56 $<X<95.54$ untuk kategori sedang, dan $X \geq 95.54$ untuk kategori tinggi pada kelas eksperimen dan kontrol. Berdasarkan analisis pengelompokan Self Confidence, diperoleh untuk kelas eksperimen 7 siswa untuk kategori tinggi, 18 siswa untuk kategori sedang dan 5 siswa untuk kategori rendah. Sedangkan untuk kelas kontrol diperoleh diperoleh 6 siswa dengan untuk kategori tinggi, 17 siswa untuk kategori sedang dan 7 siswa untuk kategori rendah. 


\section{Uji Hipotesis II}

Analisis data untuk hipotesis kedua menggunakan anova dua arah (two way anova), uji anova dua arah untuk melihat perbedaan kemampuan komunikasi matematis siswa berdasarkan self confidence. untuk menguji hipotesis 2 maka teknik analisis yan peneliti gunakan adalah anova dua arah. Hasil analisis data menunjukan nilai $F(A \times B)_{\text {hitung }}=-1.97$ $F(A \times B)_{\text {tabel }}=3,17$ pada taraf signifikan $5 \%$. Dengan kesimpulan bahwa $F(A \times B)_{\text {hitung }}<F(A \times B)_{\text {tabel }}$ yang berarti $H_{0}$ diterima dan $H_{a}$ ditolak, sehingga dapat ditunjukan bahwa tidak terdapat pengaruh interaksi antara model pembelajaran dengan Self Confidence terhadap kemampuan komunikasi matematis siswa.

\section{SIMPULAN DAN SARAN}

Berdasarkan hasil penelitian dan analisis data yang telah dilakukan, model pembelajaran CTL terhadap kemampuan komunikasi matematis berdasarkan self confidence siswa SMP/MTs dapat disimpulkan bahwa: (1) Terdapat perbedaan kemampuan komunikasi matematis antara siswa yang belajar dengan model pembelajaran CTL dengan siswa yang belajar menggunakan pembelajaran konvensional. (2) Tidak terdapat interaksi antara model pembelajaran CTL dengan self confidence siswa dalam meningkatkan kemampuan komunikasi matematis siswa.

\section{DAFTAR RUJUKAN}

Abdi, M., \& Hasanuddin, H. (2018). Pengaruh Model Pembelajaran Think Pair Share dan Motivasi Belajar terhadap Kemampuan Komunikasi Matematis Siswa Sekolah Menengah Pertama. JURING (Journal for Research in Mathematics Learning), 1(2), 99-110.

Firmansyah, A., Hasanuddin, H., \& Nelson, Z. (2018). Pengaruh Model Pembelajaran Contextual Teaching and Learning terhadap Kemampuan Komunikasi Matematis Berdasarkan Pengetahuan Awal Siswa. JURING (Journal for Research in Mathematics Learning), 1(1), 01-10. https://doi.org/10.24014/juring.v1i1.4772

Hendriana, H., Rohaeti, E. E., \& Sumarmo, U. (2017). Hard skills dan soft skills matematik siswa. Bandung: Refika Aditama.

Ina V.S. Mullis, Michael O. Martin, Pierre Foy, \& Alka Arora. (2012). TIMSS 2011 International Results in Mathematics. Retrieved from https://timssandpirls.bc.edu/timss2011/international-results-mathematics.html

Menteri Pendidikan dan Kebudayaan Republik Indonesia. Standar Isi Pendidikan Dasar dan Menengah. , Pub. L. No. 64 (2013).

Menteri Pendidikan Nasional. Standar Isi untuk Satuan Pendidikan Dasar dan Menengah. , 22 § (2006).

National Council of Teachers of Mathematics. (2000). Principles and Standards for School Mathematics: An Overview. Reston, Virginia: National Council of Teachers of Mathematics.

OECD. (2018). PISA 2015 results in focus. Retrieved from https://www.oecd.org/pisa/pisa-2015-results-in-focus.pdf

Rahmayanti, K. R., Hasanuddin, H., \& Nelson, Z. (2018). Pengaruh Penerapan Metode Pembelajaran Aktif Modeling The Way terhadap Kemampuan Komunikasi Matematis Ditinjau dari Kemampuan Awal Siswa SMK Taruna Pekanbaru. JURING (Journal for Research in Mathematics Learning), 1(1), 65-70. https://doi.org/10.24014/juring.v1i1.4774

Sugiyono. (2012). Metode Penelitian Kuantitatif Kualitatif dan REDD - Penerbit Alfabeta. Retrieved from http://cvalfabeta.com/0223-detail-metode_penelitian_kuantitatif_kualitatif_dan_r\&d.html

Syasri, S. I. R., Hasanuddin, H., \& Noviarni, N. (2018). Peningkatan Kemampuan Komunikasi Matematis: Pengembangan Lembar Kerja Siswa Berbasis Model Pembelajaran Kooperatif Tipe Think Talk Write untuk Siswa Sekolah Menengah Pertama. JURING (Journal for Research in Mathematics Learning), 1(1), 43-54. https://doi.org/10.24014/juring.v1i1.4770

Wahyuni, E. T., Hendryawan, S., Nasrullah, A., \& Wachyar, T. Y. (2018). Meningkatkan Kemampuan Komunikasi Matematis Siswa SMP Melalui Pembelajaran Think Pair Share (TPS). Symmetry: Pasundan Journal of Research in Mathematics Learning and Education, 3(2), 125-136. https://doi.org/10.23969/symmetry.v3i2.1253

Wijayanto, A. D., Fajriah, S. N., \& Anita, I. W. (2018). Analisis Kemampuan Komunikasi Matematis Siswa SMP Pada Materi Segitiga dan Segiempat. Jurnal Cendekia: Jurnal Pendidikan Matematika, 2(1), 97-104. https://doi.org/10.31004/cendekia.v2i1.36 